\title{
Grounded Theory as an Approach for Exploring the Effect of Cultural Memory on Psychosocial Well-Being in Historic Urban Landscapes
}

\author{
Fatmaelzahraa Hussein ${ }^{1,2, *(\mathbb{D})}$, John Stephens ${ }^{1} \mathbb{D}$ and Reena Tiwari ${ }^{1}$ \\ 1 School of Design and Built Environment, Curtin University, Perth, WA 6845, Australia; \\ j.stephens@curtin.edu.au (J.S.); r.tiwari@curtin.edu.au (R.T.) \\ 2 Department of Architectural Engineering, High Institute of Engineering and Technology, \\ El Behira 22699, Egypt \\ * Correspondence: f.hussein@postgrad.curtin.edu.au; Tel.: +61-469606078
}

Received: 26 October 2020; Accepted: 23 November 2020; Published: 27 November 2020

\begin{abstract}
Although grounded theory (GT) has emerged as a popular research approach across multiple areas of social science, it has been less widely taken up by researchers working in the fields of urban planning and design. The application of GT enables uniquely innovative insights to be gained from qualitative data, but it has attracted criticism and brings its own challenges. This paper proposes a methodology that could be applied by other researchers in the field of urban research. Utilising constructivist GT as a qualitative approach, this research investigates how cultural memory impacts the psychosocial well-being and quality of life (QoL) of users of, and visitors to, historic urban landscapes (HULs). Based on the findings, it can be posited that the application of GT yields a rich and nuanced understanding of how users of HULs experience the settings in which they live, and the impact and significance on human psychosocial well-being of the cultural memories incarnated within such settings. The current paper also contends that GT enables researchers studying the built environment to construct inductively based theories. Lastly, the practical implications of developing GT for application to HUL management are discussed, both in regard to how users experience the contexts in which they live and the impact of such contexts on well-being and quality of life.
\end{abstract}

Keywords: Alexandria; constructivist grounded theory; historic urban landscapes; qualitative research; quality of life

\section{Introduction}

The field of urban research is multidisciplinary, incorporating insights from the fields of, inter alia, landscape architecture, urban planning, design, and management. A commonality across all disciplines involved is that researchers and practitioners must use robust and innovative research techniques to understand and respond to the complexity, dynamism, and fluidity of the urban phenomena they seek to understand. Traditionally, research within these disciplines has concentrated largely on the physicality of the built environment, with a strong emphasis on practice over theory (Allen and Davey 2018). In contrast, this paper champions the use of constructivist grounded theory (GT) as a means of investigating the impact of cultural memory on the psychosocial well-being and quality of life (QoL) of users of historic urban landscapes (HULs). To do this, the paper refers to case studies previously conducted at three sites in Alexandria, Egypt, in the Orabi Square, Masrah $\mathrm{Al}$ Salam context and Zanqit Alsitat market. Each of these places have been the subject of published research papers (Hussein et al. 2020a, 2020b, 2020c) that have developed GT to advantage in analysis. This paper uses these case studies as a ground for the discussion of GT as an approach for exploring 
the effect of cultural memory on psychosocial well-being in historic urban landscapes. In this context we are also reviewing the efficacy of the GT approach and supporting more widespread use in urban conservation analysis.

The paper is organized as follows: First, a background for the investigated research topic main concepts is introduced. Second, a definition of GT and a description of constructivist GT approach is given, followed by a justification for its choice in investigating HULs. Finally, the application of the theory to the topic under investigation is described, and the limitations of this approach to the study of urban planning and management are outlined.

\subsection{Background}

Historic urban landscapes (HULs) have gained great attention since the United Nations Educational, Scientific and Cultural Organization (UNESCO) 2011 recommendations aimed to manage the physical deterioration of historic urban settings (Bandarin and Oers 2015). These recommendations were inclusive in defining the HUL as "the urban area understood as the outcome of a historic layering of cultural values and natural attributes, that extends beyond the idea of 'ensemble' or 'historic centre' to involve the wider urban context and its geographical setup" (Aysegul 2016). A concern of the UNESCO recommendations are the values that people place on history and memory and their retention in the development of HULs (Bandarin and Oers 2015). Memory is defined as our mental capacity to retain and revive events and to recall our previous experiences-abilities that help to preserve our past (Boyer 1994). Memory can be individual or collective/cultural. Cultural memory is the act of recalling events that are related to encounters with objects, places, and events by people in a social framework or between groups that experience these events (Molavi et al. 2017).

The concept of cultural memory was first introduced by Maurice Halbwachs in his books The Social Frameworks of Memory (1925 and 1992), and On Collective Memory (1980 and 1950). He built his explanation of cultural memory on differentiating between individual and collective memory, as he described individual memory as "personal" and "autobiographical," and collective memory as "social" and "historical" (Halbwachs 1992). Following the introduction of the concept, other theorists built on Halbwachs's understanding, such as Pierre Nora, who further studied spatial collective memory (Nora 1989), and Aldo Rossi, who introduced "urban memory" in his book, The Architecture of the City, which allowed collective memory to be studied in architecture and urban design (Jahanbakhsh et al. 2015). Christine Boyer also added to this discussion in her book City of Collective Memory, in which she explains that a city's architecture is what controls its collective expression and carries the traces of earlier architectural forms, along with the city's planning and monuments (Boyer 1994). These authors' contributions explained that recalling cultural memory is place-specific, and landscapes as places are vessels for family stories and community memories (Li 2010). They also showed that there is a link between cultural memories, everyday activities, and landscapes, forming a clear sense of the past and reinforcing attachment to places (Jahanbakhsh et al. 2015).

Place attachment is understood to be the degree to which an individual values their bond with a given environment (Ramkissoon et al. 2012). Scholars have defined it as "the bonds that people develop with places" (Giuliani 2003) and it includes three components (Altman and Low 1992): first, the affective component, which is reflected in the emotional attachments to places; second, the cognitive component, which includes thoughts, knowledge, and beliefs related to places; and third, a practice component that refers to the behaviour and activities that occur within spatial contexts (Kyle et al. 2004). Attachment to a place is developed when the place is significant and well identified by users, when it fulfils the users' functional needs and supports their behavioural goals better than any known alternative (Williams et al. 1992). This points to another important concept when dealing with the bonds people have with places_-"place identity." Scholars define place identity as "the set of features that guarantee the place's distinctiveness and continuity over time" (Lewicka 2008). Anton and Lawrence suggest that a place possesses identity when it evokes in people feelings of specialness, happiness, being in control, and self-pride (Anton and Lawrence 2014). 
To deepen our understanding of the construction of place identity, it is important to elaborate not only on the socio-environmental values stored in a specific society, but also how this society's inhabitants relate to their environment. Considering this miscellaneous relationship between people, place, and values enables us to give more focus to psychosocial and emotional senses of place and belonging on physical attributes (Cheshmehzangi and Heat 2012).

Psychosocial well-being is a growing multidisciplinary area of research that is studied by a number of sciences and research fields, such as environmental psychology, geography, and sociology. It deals with the close connection between the psychological aspects of our experiences (e.g., our thoughts, emotions, memories, and behaviour) and our wider social experience (e.g., our relationships, traditions, and culture) (INEE 2017). Psychosocial well-being in architectural research shows strong cross relations with the concept of "sense of place," which is theoretically explained as the integration of psychological, social, and environmental operations in relation to physical places (A. Williams et al. 2008).

A number of scholars have theorised about sense of place (e.g., Relph 1976; Tuan 1980; Steele 1981; Eyles 1985; Jackson 1994; Hay 1998). It was defined as the complex bundle of meanings, symbols, and qualities that a person or a group associates with a particular region (Shamai and Ilatov 2005). David Hummon (1992) elaborated on the concept of sense of place, explaining that it is dual in nature, involving both an informative perspective on the environment and an emotional reaction to it (Hummon 1992).

Other scholars considered sense of place an umbrella concept that covers all the relationships people form with places, such as emotional bonds; the strong felt meanings, memories, values, and symbols; the valued qualities of the place; and the awareness of the historical and cultural significance of the place (Williams and Stewart 1998). Eisenhauer considered that sense of place consists principally of the social interactions that occur in a place and the memories associated with it (Brian et al. 2000). Hence, there is a relationship between cultural memory and HULs, which sheds the light on the importance of sense of place and the value of place, especially intangible values such as emotions. Accordingly, this paper endeavours to deepen our understanding of the role of cultural memory in achieving psychosocial well-being in historic urban landscapes.

\subsection{Problem Statement}

Conventional urban conservation practices have tended to concentrate on two particular aspects of HULs, namely how they function as lived spaces and how they are perceived by their users. However, less attention has been paid to their function as repositories of affective and cognitive psychosocial experiences on both the collective and individual level (Ujang and Zakariya 2015). It is true that the HUL approach acknowledges the existence of a cultural (collective) memory (UNESCO 2016); however, conservation planning takes little account of how this cultural memory impacts the psychosocial well-being of inhabitants (Carone et al. 2017). The current research aims first to fill this gap through the application of GT, and second, to also fill a gap in urban conservation research, namely how psychosocial well-being relates to HULs. Lastly, this research has the more practical aim of elaborating a methodology that can be applied to similar settings in the future.

\subsection{Defining Grounded Theory}

Qualitative research can be used in many different research settings and encompasses multiple methodologies based on a range of sometimes contrasting theoretical assumptions (Flick 2002). GT can be conceptualized as a flexible tool to carry out systematic inductive qualitative research into theory development (Charmaz 2005). In contrast to deductively obtained methods, it is a theory that is systematically obtained through "social" research and is grounded in data (Goulding 1998). It has emerged as a widely-used research approach across the social sciences, particularly nursing and the health sciences, as it gives researchers the flexibility to develop, test, and strengthen new theories from their research data in cases when no suitable theory has yet been formulated (Achora and Matua 2016). 
GT has therefore become regarded as a useful tool for researchers seeking to conceptualize social and human-centered phenomena in innovative ways (Compton and Barrett 2016).

Within disciplines such as architecture, landscape architecture, urban planning, design, and management, however, GT has been little used, largely because urban research has conventionally focused on the complex and dynamic physicality of urban environments and has tended to privilege practice over theory (Allen and Davey 2018).

In terms of the value of GT to the collation, synthesis, analysis, and conceptualization of qualitative data, Charmaz (2015) underlines the benefits of its inductive, iterative, interactive, and comparative nature, as well as the robust scaffolding it offers for theory construction. GT brings together elements of multiple qualitative research methods to create a systematic roadmap whereby data can be simultaneously, rather than sequentially, processed during both collection and analysis phases, with the aim of deriving an inductive theory about a particular phenomenon (Strauss and Corbin 1998). Hence, researchers are able to produce conceptually dense theories in which relationships between concepts are systematically ordered to reveal "patterns of action and interaction between and among various types of social units" (Strauss and Corbin 1998). For this reason, researchers looking to compare and explain case studies often use GT.

GT emerged in the early 1960s in the United States because of the confrontation between qualitative and quantitative studies. Qualitative researchers at that time were applying for field work, gathering large amounts of data, and showing relationships; however, they didn't apply an analytical approach or use analytical strategies such as those used in quantitative studies (Charmaz 2014). In response to this "extreme positivism," Barney Glaser and Anselm Strauss (1967) founded GT and described it in their book The Discovery of Grounded Theory (Glaser 1967). Known as the "classic GT," Glaser's and Strauss's contribution redirected qualitative research towards more empirical findings and offered the first systematic method for analysing qualitative data (Charmaz 2015). In this process repeated concepts "emerge" from the data. Concepts are summarised into codes which-with the benefit of further data-are placed into higher level "categories" that may provide the basis for hypothesis. This gradual emergence of theory from the coding of data is different than the usual scientific method where an existing theory is used from the outset to frame the data.

Later, Strauss and Corbin (1998) remodelled the classic GT as they adopted different philosophical and methodological perspectives (see Table 1) from those of Glasser (Mills et al. 2016). Within this version, known as the Straussian GT, these authors argued that literature can be valuable to the early stage of research to form questions that act as a starting point during initial observations and interviews (Strauss 1990). The key way that the Straussian GT approach differed from the classic GT was in adding another layer to the coding process, which is an axial coding (a more structured form of coding) to increase the validity of findings (Gary 2013).

Charmaz (2000) identified the positive features of both the aforementioned GT versions and built on the Straussian GT approach, forming the most recent "constructivist GT" version (Charmaz 2000). Unlike the earlier versions, her approach took into account the subjectivity of the researcher and other research participants by focusing on a descriptive theory based on believing that theories are constructed and not discovered. Accordingly, Charmaz's approach elaborated the relationships between the viewer and the scene, fact, and value, and the research conditions and its products (Charmaz 2015). 
Table 1. Differences between classic GT and Straussian GT versions (Allen and Davey 2018).

\begin{tabular}{|c|c|c|}
\hline Differences & Classic GT (Glaser and Strauss) & Straussian GT (Strauss and Corbin) \\
\hline Nature & $\begin{array}{l}\text { A general methodology that uses } \\
\text { qualitative/quantitative data. }\end{array}$ & $\begin{array}{l}\text { A qualitative methodology using } \\
\text { qualitative data. }\end{array}$ \\
\hline Approach & $\begin{array}{ll}\text { - } & \text { Inductive } \\
\text { - } & \text { (objectivist method) }\end{array}$ & $\begin{array}{ll}\text { - } & \text { Inductive } \\
\text { - } & \text { (post-positivist approach) }\end{array}$ \\
\hline Theoretical Sampling & $\begin{array}{l}\text { Data collection for } \\
\text { generating theory. }\end{array}$ & $\begin{array}{l}\text { Data gathering derived by the } \\
\text { concepts roused from the evolving } \\
\text { theory and based on } \\
\text { making comparisons. }\end{array}$ \\
\hline Theoretical Sensitivity & $\begin{array}{l}\text { - Comes from immersion into data. } \\
\text { Theory is derived from being open } \\
\text { with no preconceived theory } \\
\text { in mind. }\end{array}$ & $\begin{array}{l}\text { Comes from applying methods } \\
\text { and tool on data (e.g. continuous } \\
\text { questioning and comparisons). }\end{array}$ \\
\hline The Use of Literature & $\begin{array}{l}\text { No use of literature prior to theory } \\
\text { development. Pre-study literature } \\
\text { is considered a waste of time. }\end{array}$ & $\begin{array}{l}\text { Possible to use literature in before } \\
\text { empirical stage, to familiarise } \\
\text { better with the } \\
\text { researched phenomena. }\end{array}$ \\
\hline Procedures and Techniques & $\begin{array}{l}\text { Applies procedural flexibility and } \\
\text { simplicity. Objects the use of } \\
\text { computer programs. }\end{array}$ & $\begin{array}{l}\text { - Reduced the method to procedures } \\
\text { and minimised flexibility. } \\
\text { Welcomed the use of } \\
\text { computer programs. }\end{array}$ \\
\hline Memo Writing & - Theoretical notes about data. & $\begin{array}{l}\text { Not just descriptive notes; they } \\
\text { contain directions and outcomes } \\
\text { for the analyst. They are analytical } \\
\text { and conceptual. }\end{array}$ \\
\hline Coding & $\begin{array}{l}\text { - Theoretical coding: open coding } \\
\text { and selective coding }\end{array}$ & $\begin{array}{l}\text { Substantive coding: open coding, } \\
\text { axial coding, and selective coding. }\end{array}$ \\
\hline
\end{tabular}

Charmaz (2006) extended the approach by suggesting that researchers should undertake theory formation and a literature review before embarking on data gathering. It should be noted, however, that her suggestion contrasts with the conventional GT view that people gather data by experiencing it and understanding its impact on their conceptions of the world (Charmaz 2006). For Charmaz (2006), a constructivist GT approach requires that six basic elements be present in the research process (González-Teruel and Abad-García 2012):

- Data are simultaneously gathered and analysed;

- Analytic categories (codes) are constructed from the data, rather from a hypothesis deduced prior to data-gathering;

- Comparison of data is undertaken at every stage;

- Theory development remains constant throughout each stage of data gathering and analysis;

- Researchers keep notes and memos of the categories under creation, along with their specific properties and relationships to each other and any gaps which emerge; and

- Sampling is chosen to aid the construction of theory, rather than to represent a given population. 
In this context, constructivist GT can be considered the ideal vehicle for urban research because of its view of rejecting the notion of emergence (that researchers can enter their studies uninfluenced by earlier studies and their own backgrounds and interests) and objectivity (that research is value-free) (Charmaz 2000), which helps in removing the limited approaches that emerge from regular planning views (Friedmann 1998). In addition, it is of value to researchers who are focusing on how the process of considering how subjective/intangible experiences can form theoretical perceptions regarding collective interpretations or relationships amongst actors. Constructivist GT ideally informs urban research since all human scaled experiences and responses are contextualised within a place or an urban setting. Finally, it enables researchers to construct and develop strong theory where key research concepts do not exist or may be unclear or even under-researched (Alves de Sousa and Hendriks 2006).

Accordingly, constructivist GT was chosen as the most suitable approach for the research described in this paper because:

- The complex social experiences of users and visitors to HULs are examples of the phenomena that GT was specifically devised to investigate and explain;

- $\quad$ Researchers using constructivist GT are required to perform a literature review before the empirical stage to better familiarise themselves with the researched phenomena and identify the research initial concepts;

- $\quad$ Researchers using constructivist GT are required to immerse themselves in the research setting and the data gathered from it in order to gain rich and nuanced insight into a multilayered and multisubject phenomenon;

- It is based on the real, firsthand experience of the phenomenon under investigation (Charmaz 2000);

- It gives researchers a comprehensive understanding of how users believe they inhabit and experience their worlds (Charmaz 2000); and

- It enables the collection of rich data that reflect multiple perspectives and prioritize memory, meaning, and interpretation.

\section{Research Design}

This section outlines how constructivist GT was used in each stage of this research, from determining the scope through integrating the literature to drawing up interview questions and analysing collected data (see Figure 1).

\section{Applying Constructive Grounded Theory}

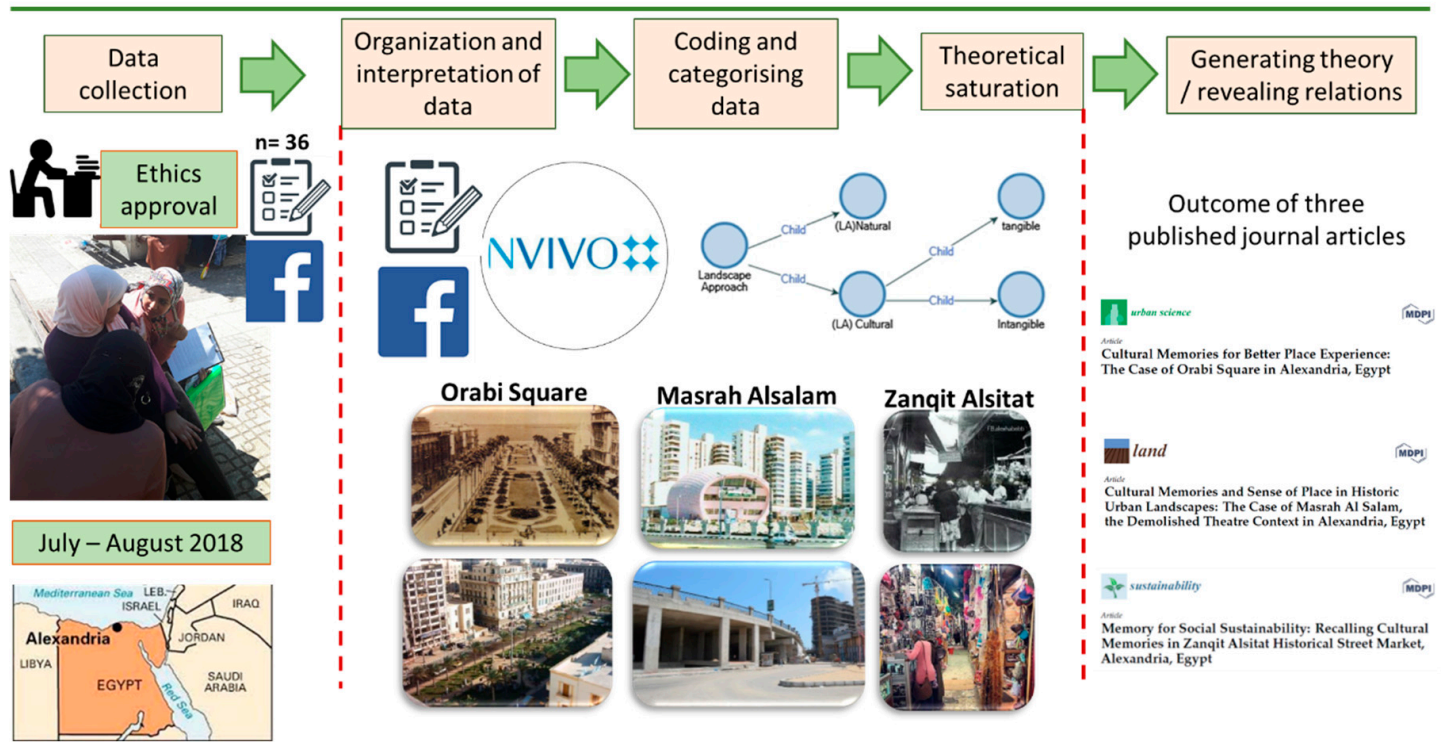

Figure 1. Diagram showing the stages of applying constructivist GT for this research. Source: F. Hussein. 
Answering the main questions posed in the problem statement regarding the role and impact of cultural memory in conservation planning in HULs required four principal objectives to be met:

1. To examine the current conservation and HUL concepts and themes;

2. To analyse the relationship between cultural memory, HUL, and psychosocial well-being;

3. To study the extent of present HUL management practices needed to maintain cultural memory and achieve well-being; and

4. To investigate the proposed changes needed for new HUL management plans that would help in maintaining psychosocial well-being.

To this end, the study was broken down into three phases: namely, a critical analysis of the extant literature, empirical research, and formulating conclusions and recommendations, as depicted in Figure 2.

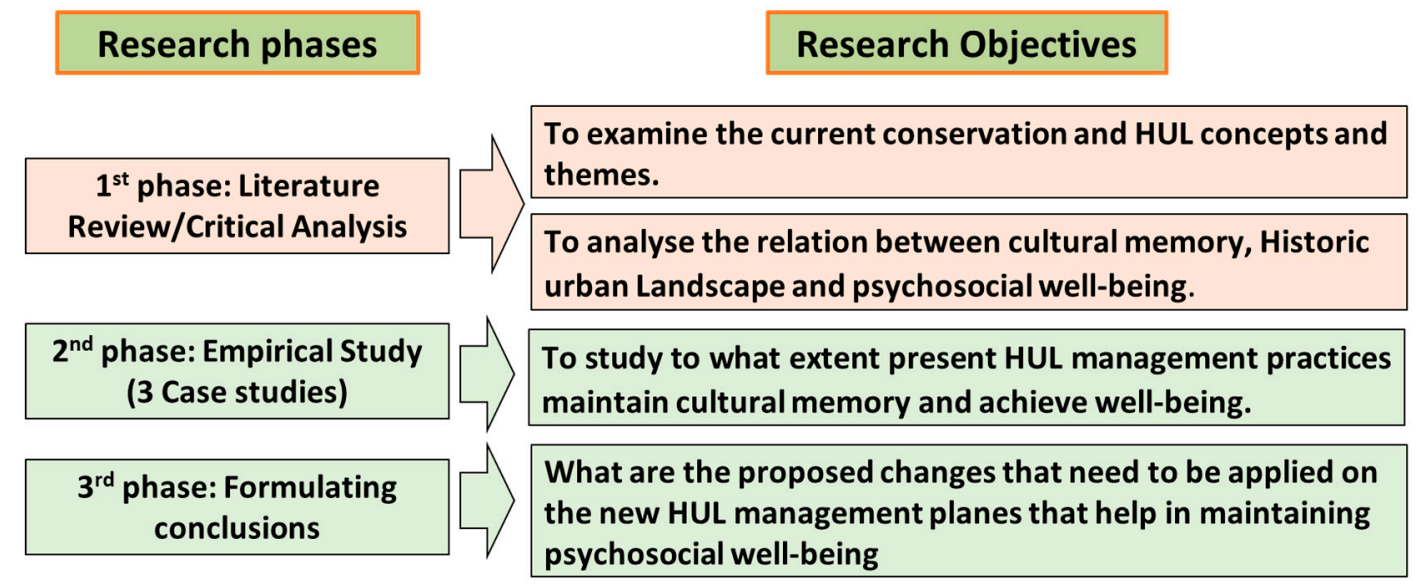

Figure 2. The three research phases and the intended research objective of each phase. Source: F. Hussein.

\section{Research Process}

\subsection{Literature Review Critical Analysis (First Phase)}

This stage in the research aimed to bring together and interpret relevant data uncovered by other scholars and practitioners to draw up preliminary findings (Skene 2016). Relevant primary sources were sought in repositories such as governmental and other archives, map libraries, and photo databases, after which secondary sources were identified, including published books and journal articles as well as academic theses and dissertations in related fields. All these resources were studied so that data collected at a later stage could be theorised and better critically analysed. Likewise, a critical analysis was carried out of the four main terms used in this research, these being cultural memory, HULs, sense of place, and psychosocial well-being, with the aim of revealing relations, differences, and commonalities among them. The literature review also strengthened and refined the concept underpinning this research and informed the drawing up of the interview questions.

\subsection{Empirical Study (Second Phase)}

Under empirical study, the primary data investigated and analysed were gathered during fieldwork and came from the direct observation or experience of the researcher (SDU 2020). The empirical data for the current study were gathered to cover each of the three selected HULs in the Egyptian city of Alexandria.

\subsubsection{Setting}

Alexandria was founded by Alexander the Great in 331 B.C. on the site of an existing small settlement. For a millennium, the city was among the most important hubs of the Greek and Roman Empires. When the Arabs began their conquest of Egypt, however, in A.D. 641, they created a new 
capital at Fustat (now part of Cairo) and Alexandria diminished in importance. Today, it is Egypt's most important port (see Figure 3) and second largest city, with a population of approximately 5.2 million inhabitants in 2018 across an area of 2679 square kilometres (Alexandria 2019). The current research focuses on Alexandria not only because of its historical value but also because it encompasses several HULs in need of replanning and renovation, most of which are repositories of cultural memories and sentiment that are not considered under the current governmental approach to redevelopment. The current approach takes account only of the tangible benefits to be gained, for example, in terms of meeting the needs of a growing population by improving urban infrastructure. However, it has not consulted research into the relationship between sense of place and psychosocial well-being, which is a vital part of maintaining not only the image but also the identity of one of the most ancient cities in the wider Middle Eastern and Mediterranean region.

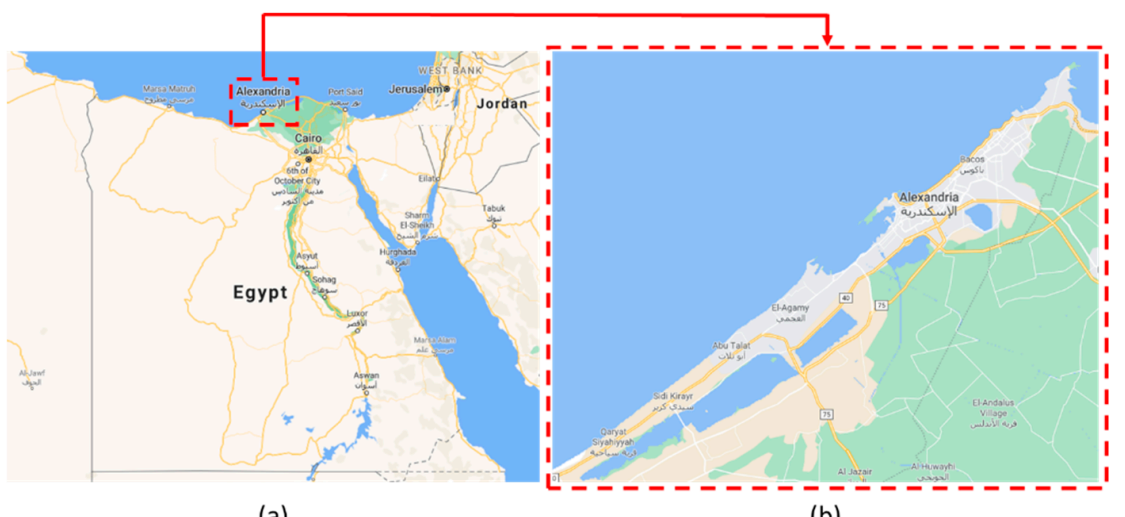

(a)

(b)

Figure 3. The location of Alexandria in Egypt. (a) Map of Egypt. Source: (GoogleMaps n.d.). (b) Alexandria map. Source: (GoogleMaps n.d.).

Three HULs were chosen for investigation, each representing a different facet of urban life: a public square, the context of a well-known theatre that was recently torn down, and a historic street market. It was decided to select sites representing different functionalities and user types not only to ensure rich data but also to give a holistic answer to the research questions. More information is given on each study site below.

(a) Orabi Public Square ("French Gardens," Les Jardins Français)

The famous gardens of Orabi Square were situated within the old district of El Mansheya in the heart of the city. In its heyday, it extended from Mohamed Ali Square south to the Mediterranean corniche at the seafront in the north. (see Figure 4a). The square gained its original name-the French Gardens, or Les Jardins Français-because it was home to the French Consulate under the early-19th-century regime of Muhammad Ali Pasha, Commander of Egypt, and the gracious, symmetrical buildings that surrounded it were typically French in appearance (Alexandria Egypt Land Meets Water 2012). When the gardens were destroyed in the 1960s and replaced by a bus station, Orabi Square became one of Alexandria's most densely trafficked areas until the station itself was removed some two decades later and the square was restored to its original use. However, today's Orabi Square departs substantially from the old French plan. At the northern end, the vast neoclassical structure facing seawards was donated by the city's Italian community just before World War II and dedicated to Khedive Ismail, then-ruler of Egypt. In 1966, it was re-dedicated to "the Unknown Sailor" (Awad 1996). The value of this site to the present research lies in its status as an important example of a rehabilitated public meeting place, located in the oldest part of Alexandria, which has been not only been rebuilt but fundamentally repurposed several times. Hence, it is a useful site to illuminate the principal question of this research, namely, the extent to which current HUL management practices ensure cultural memory is maintained and promote the psychosocial well-being of urban users. 

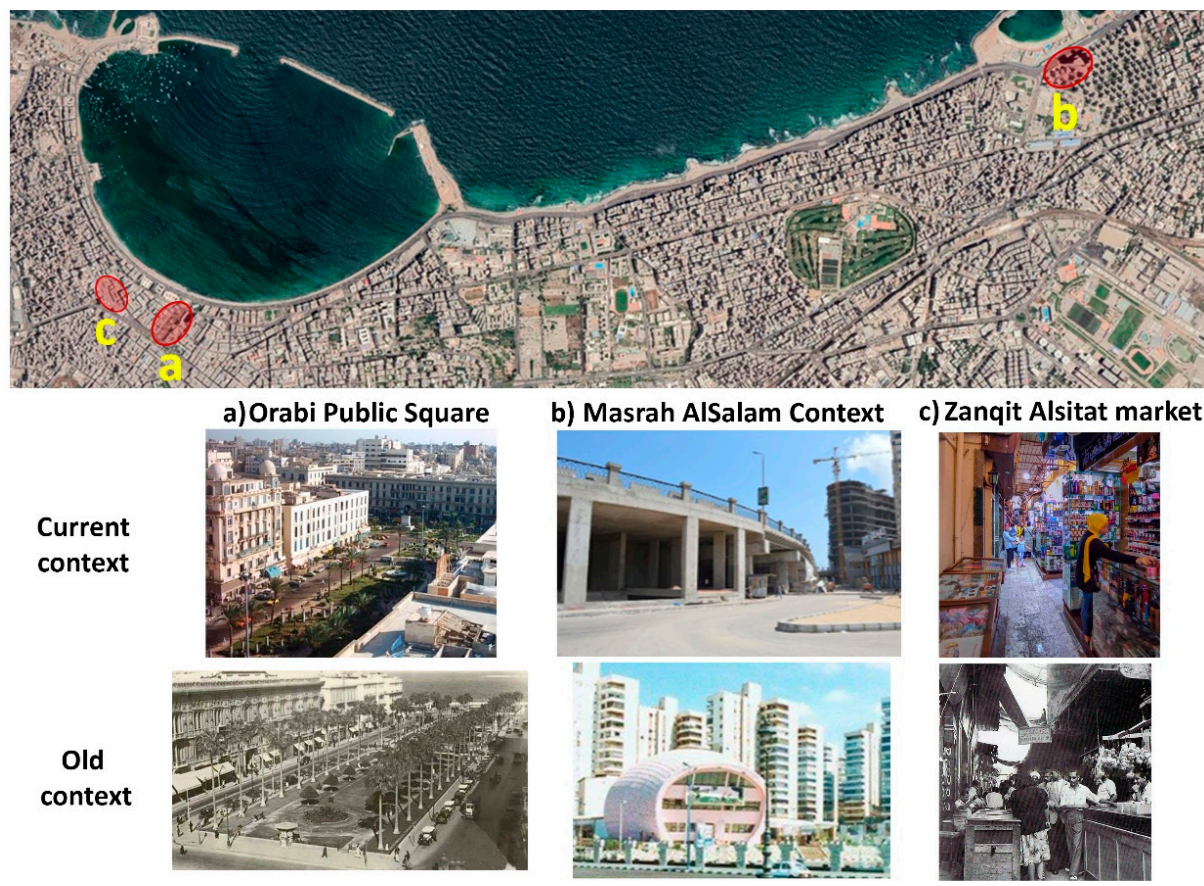

Figure 4. The location of the three studied historic urban landscapes (HULs) within Alexandria. (a) Orabi Public Square, upper photo for the current context. Source: F. Hussein. The lower photo for the previous context. Source: (Twitter.com 2018). (b) Masrah Al Salam, upper photo for the current context. Source: F. Hussein. The lower photo for the previous context. Source: (Zeinobia 2016). (c) Zanqit Alsitat historical street market, upper photo for the current context. Source: Heba Moanis. The lower photo foe the previous context. Source: (Alexandria 2020).

\section{(b) Masrah Al Salam (Al Salam Theatre) Context}

The Masrah Al Salam (Al Salam Theatre) is located in the Mustafa Kamel district in the eastern part of the city. Designed by architect Samir Rabee (1936-2016), it was opened in 1954 and swiftly became one of the most memorable structures on the corniche (see Figure $4 \mathrm{~b}$ ), gaining fame as one of the few buildings in the country to feature an elliptical form and innovative shell structure system (Morgan 2016). For 62 years, it was among the city's most venerable institutions, having put on Egypt's best-known plays, starring the nation's best-loved actors, for generations of Alexandrians (Deyaa 2016), who loudly demonstrated their disapproval when it was demolished in 2016. Although the theatre had been shut for about five years before its demolition and become increasingly dilapidated, its removal was a blow to people who saw it as a vital part of how they perceive and understand their surrounding context.

\section{(c) Zanqit Alsitat Historical Street Market}

Located in the city's El Mansheya district, Zanqit Alsitat is Alexandria's most important and best-known historic suq (market) (see Figure 4c). It is not known when exactly it came into being: Some date it to the arrival of Napoléon's troops (as the ruins of French army stables lie beneath it), but most believe it was built in the 18th century under the Ottoman ruler Mohamed Ali, due to its location within the city's old "Turkish Town." This would make it the only Ottoman suq still in existence in the city (Hanafi 1993). A maze of cramped, narrow streets with multiple exits and entries, the suq looks very much as it did when it was originally built, except that extra storeys have been added to some of the houses (Asem 2009).

The Zanqit Alsitat suq was selected for this study because of its cultural value as one of the very few original constructions in "Turkish Town." It is still a busy place of commerce, with the throngs of people who visit every day partly responsible for the severe damage to its fabric and increasing levels of pollution that threaten to negate the social and cultural benefits it confers. The lack of formal renovation or management, however, at least means it has not suffered clumsy interventions. Hence, 
it is ideal for the examination of how cultural memories can be maintained through place, and how future redevelopment plans should be shaped to promoted social inclusion and sustainability.

\subsubsection{Methods of Data Collection}

Narrative data were collected via semi-structured in-depth interviews. The interview questions were formulated following the first research phase and were designed to enclose all concepts emerging from the key research question's related literature review (see Appendix A). Fourteen questions were developed, and the interview was piloted by two participants in order to check that all questions were clear and estimate how much time participants would have to give up. Minor modifications were made to the wording of some questions, and seven extra questions were added to make a total of 21 . All questions were first written in English, then translated into Arabic by the researcher (F. Hussein, the first author), who is a native speaker of Arabic, then back-translated to check accuracy.

Baker and Edwards (2012) argued that there is no specific rule on how many interviews are required within qualitative research (Baker and Edwards 2012). Twelve interviews for each selected HUL were conducted for this research, giving 36 interviews in total, in accordance with Morse's (1994) suggestion that a minimum of five participants is necessary if qualitative research is to adequately reflect the nature of a given experience.

The random sampling technique was used, with the researcher (F. Hussein, the first author) approaching possible interviewees in the street and asking if they were willing to participate. This sampling method ensures that every individual in a given population has an equal probability of being selected (Meng 2013). Two main interview types (clusters) were approached. Among the first, categorized as static users (in a state of constant engagement with the HUL), were merchants of all levels, from shop owners through street vendors, as well as office workers, residents, and students. Among the second, categorized as mobile users (with less than daily engagement with the HUL), were visitors and shoppers.

The final 21-question interview was designed to elicit data illuminating the conceptual themes of the research. Interviews were carried out in situ between July and August 2018 and lasted between 30 and $45 \mathrm{~min}$ each. All participants were required to answer all the questions. Before any interviews were held, ethical clearance was granted by the Research Ethics Committee of Curtin University, Australia (Permit No. HRE2018-0698). All participants received informed consent forms, were assured their data would be anonymized, and gave the researchers permission to record and transcribe the interviews.

This method was chosen because it allows respondents to position themselves as they choose within the story and thus yields data that is rich in indications of identity and belonging (Eyles 2008; Kraus 2006). A range of relationships between people and places is uncovered, creating a robust foundation on which the developing theory can be grounded (Daengbuppha et al. 2006).

"For me, Zanqit Alsitat represents the beautiful old Alexandria and my childhood memories. I used to take it as a shortcut to go to school, enjoying walking through its narrow alleys and on its distinctive floor tiles in the early mornings when the suq is still quiet. Its narrow alleys still carry the remnants of old intimate times and of memories with my friends going to buy lovely gifts such as embroidered textiles, accessories and beads, hand-made sarma, fabrics of all kinds, gemstones, silver, golds, and perfumes. Also, the place reminds me of my dad, as he used to have a shop in Faransah St. where I loved to go visit him and help him there. The street-food vendor (selling sandwiches) that still exists in front of $\mathrm{Al}$ Awkaf entrance with the smell of his delicious sandwiches is from the space features for me. This smell reminds me of the joy I had every time my dad bought me sandwiches from him. The suq lanes still exist, but the significant goods have started to change from the old days, and now most of the things are 'made in China', which is so sad!" (Zanqit Alsitat market, female interviewee, 50 years (sample of collected and analysed narratives)).

\section{(a) Observation}

Observation was carried out by the researcher (F. Hussein, the first author) by walking through the sites of interest in order to experience how they were used, as valuable visual, social, and aesthetic 
ethnographic data can all be collected in this way, including categories of land use and building type (Ingold and Vergunst 2008). Moreover, multiple visits to the sites over considerable periods of time enabled the researchers to become familiar with the people who lived in and used them; hence, it was easier to gain trust and build up a more accurate picture of patterns of behaviour and usage. The knowledge gained from observation was then fed back into the interview questions and the researchers' analysis of the responses to these to ensure participants were engaged and felt the project was relevant to their lives (Kawulich 2005).

(b) Social Media

Multiple related research studies have used Facebook as part of the data collection process, such as Gregory (2015), Patrick et al. (2011), and Van der Hoeven (2019) (Gregory 2015; Patrick et al. 2011; Van der Hoeven 2019). Guided by the mentioned studies, a public Facebook group named "Alexandria's Spirit" was created in June 2018, and photos of the three chosen HULs were uploaded in the hope that the page would attract comments on losses or changes within them. There are now 92 members of the Alexandria's Spirit page, and over 100 comments have been posted. Respondents were invited to comment however they wished, and this medium allowed participants, viewers, and readers from around the world to engage with the project. Previous researchers have found the use of social media is valuable because it encourages the formation of effective communities and the nostalgia generated by this type of commentary can be viewed as a form of social capital. In practical terms, this online tool was a useful way to supplement data gathering, as it was available around the clock and not confined to a single location. Moreover, many people find it easier to express themselves honestly online than when face-to-face with an interviewer (Wilson and Desha 2016).

\subsubsection{Data Management and Analysis}

Data were coded continually, within the three stages required under the constructivist GT approach: namely, open coding, selective coding, and theoretical coding. Open coding is the process in which the research concepts are initially refined from a sample and classified into categories. Selective coding is the process of categorizing the emerging categories into core categories by exploring the intersecting relationship between the emerging categories (Li et al. 2019). Theoretical coding is identifying and using appropriate codes to achieve a consolidated framework for the overall GT (Holton 2010). Taken together, this constant cross-comparison of data and emerging categories constitutes substantive coding, as shown in Figure 5.

The QSR NVivo12 thematic coding computer software was used to break the main research concepts/themes down into nodes and sub-nodes (A node is a collection of references about a specific theme, place, person, or other area of interest. A sub-node is a child of the node. You gather the references by "coding" sources to a node or sub-node (Nvivo10 2020). The tree-node thematic structure shown in Figure 6 was then created, which allowed the data collected through observation and interview to be triangulated (Olsen 2004). Research variable patterns were identified, which enabled meaning to be generated and a picture to be created of how cultural memory is enabling the sense of place for users of, and visitors to, the three HULs.

Comments left on the project's Facebook page were pasted verbatim into document files for coding within the same nodes and sub-nodes before qualitative content analysis was employed to identify relationships between concepts and extract findings on the feelings stirred in participants when they saw photos of the three selected HULs (Gregory 2015).

\subsubsection{Findings}

Reaching this stage of analysing and interpreting the data showed the significance of using the constructivist GT approach. Hence, immersion within the studied research settings helped the researchers to uncover the complex social experiences of the users of the HULs. For example, the Orabi Square users' experience was connected to social activities and events such as celebrating Ramadan (Muslims' holy month), whereas for users of the Masrah Alsalam context, it amplified partying feelings 
during summer holidays and activities. Finally, for the users of the Zanqit Alsitat market, plus celebrating Ramadan, the site was considered a symbol for bridal preparations for generations.

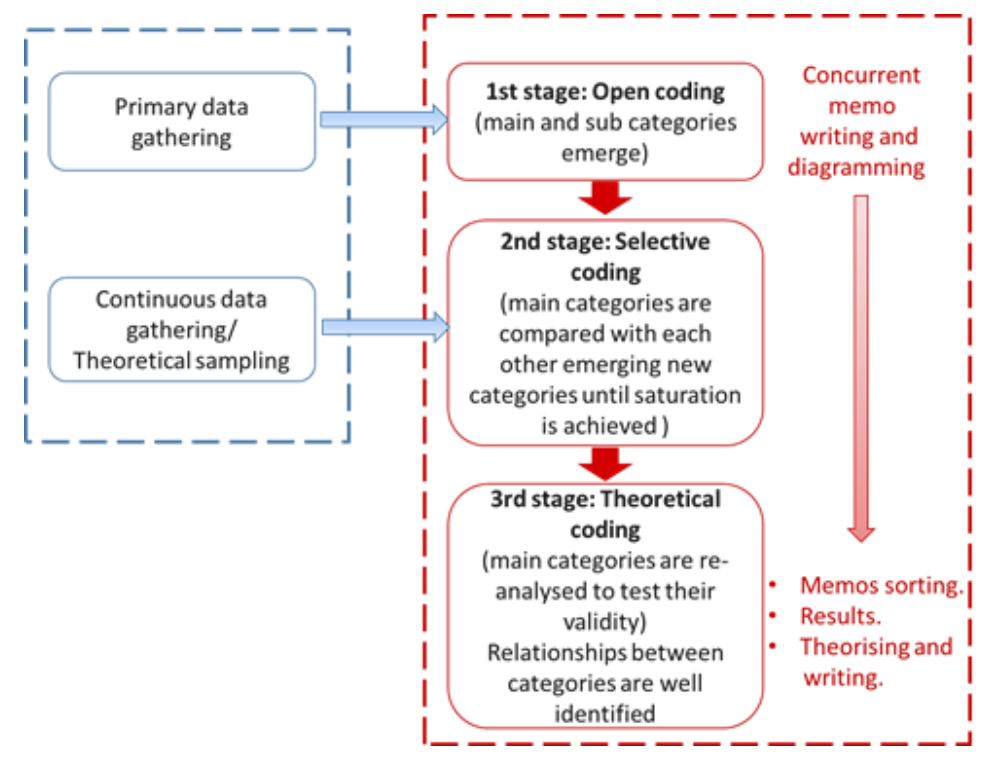

Figure 5. Constructivist grounded theory "substantive coding" coding stages used in this research. Adapted from: (Allen and Davey 2018).
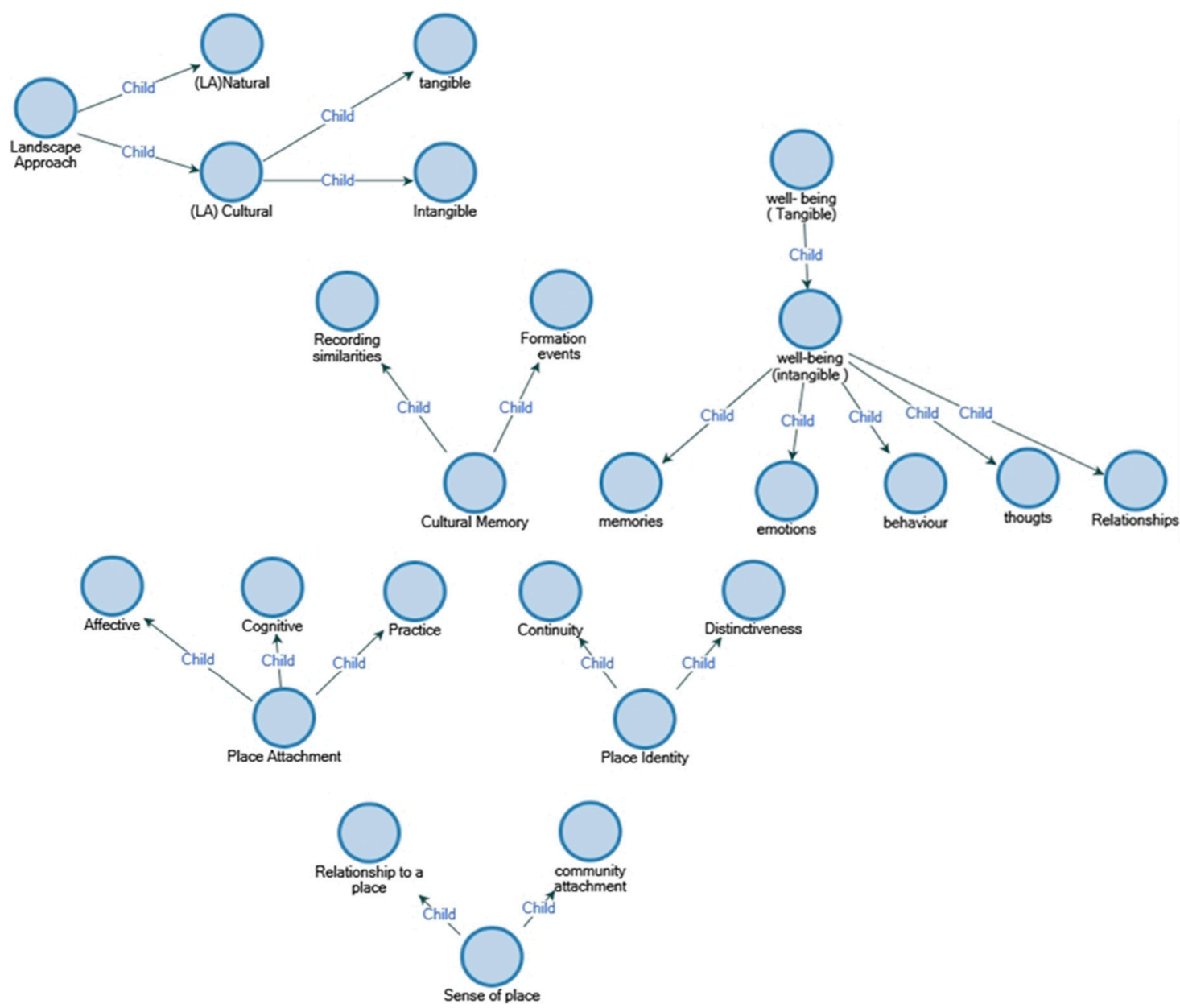

Figure 6. The main research themes used for the coding process (nodes and sub-nodes) as a tree-node diagram extracted from the NVivo12 program. Source: F. Hussein. 
In addition, using constructivist grounded theory enabled the researchers to collect rich data, such as observations, users' memories, and opinions mentioned within their narratives, and Facebook participants' narratives, which gave the researchers a comprehensive understanding of how the users inhabit and experience their worlds. Their narratives and comments stressed the importance of urban elements, such as surrounding monumental buildings in the case of Orabi Square and Zanqit Alsitat market. Even for the Marsrah Alsalam context site, the demolished theatre structure itself was necessary for the memorability of the users' urban environment. Hence, these buildings worked as urban identifiers that shaped the three HULs' place identities through their uniqueness. The rich historical data collected about the three HULs also explained the feelings of responsibility and rootedness (rootedness is a strong sense of attachment, identification, and involvement within the community (Cross 2001)) that the participants expressed through their narratives. They mentioned that they were eager to participate in any future studies to express their memories, feelings, needs, and vision.

Finally, using this approach enabled the researchers to deepen their understanding of the key research concepts in order to answer the main research question in the third phase or, in other words, construct a theory.

\subsection{Formulating Conclusions/Construction of Theory (Third Phase)}

The research objectives were met through data analysis and the subsequent findings. Specifically, a series of articles were published that dealt in detail with each of the three HULs considered. The first paper addressed Orabi Square and the research focused on two particular aspects: changes in the fabric of the site over time, and place experience. In this case study, it was demonstrated that cultural memory actively promotes emotional attachment to place, which is important in the development of a sense of place, which in turn enables higher QoL and an enhanced place experience (Hussein et al. 2020b). The second paper addressed our research into Masrah Al Salam. It described our attempt to evaluate the importance attached to cultural memory by inhabitants in the area where the iconic theatre used to stand, and to investigate to what extent cultural memory promotes their sense of place and QoL. In this case, we succeeded in showing the degree to which cultural memory attached to heritage structures underpins sense of place and fosters the identity of urban settings (Hussein et al. 2020a).

The third paper discussed the ways in which place identity, sense of place, and civic pride, with the higher QoL that results from these, are fostered by the continued presence of those elements that incarnate cultural memory within HULs. Moreover, we addressed the place and value of cultural memory within urban management and sustainable development more widely. Our study of the Zanqit Alsitat suq demonstrated a theoretical model derived from our empirical research showing how the formation of place identity, sense of place, and civic pride, which foster QoL, are the drivers of social sustainability and can be achieved by reproducing the cultural memories of HULs (Hussein et al. 2020c). Taken together, the discussions and conclusions presented in this series of articles examine the question of how important the inclusion of cultural memory is to psychosocial well-being in HUL urban conservation. Consequently, it is recommended that urban designers, city planners, and administrators should understand that psychosocial well-being in HULs can be achieved through recalling and maintaining the cultural memories rooted in HULs, which has the capacity to generate place identity, place attachment, and sense of place, and enhance place experience and QoL. In this context, cultural memory can drive social sustainability and contribute to the bigger picture of sustainable development.

\section{Conclusions}

\subsection{Strengths and Limitations}

Our study has three principal strengths. First, it is, to our knowledge, the only one of its kind to have been carried out in Egypt, where most urban research is quantitative in approach and prioritizes tangible over intangible values. Second, the typological variation in the three selected HULs allowed for a rich and multilayered discussion and analysis, and answered the research question more fully. 
Last, our findings were given added robustness because the data were collected via multiple methods, from observation and interviews to photos, social media commentary, and mental maps.

In contrast, generally the GT approach has a limitation of being very resource intensive within its whole process. The quality of its research also varies depending on the researcher's skills in performing the analysis and interpretation for the qualitative data. In addition, the researchers are requested to keep in mind being flexible and open to the emerging data to avoid any temptation rising from personal or external bias that could happen in the early stages of data analysis and could influence or change research findings.

Finally, as a specific limitation to this research, the findings are limited by the small size of the sample (albeit the number is regarded as acceptable for qualitative research) imposed by constraints on time. Nonetheless, we believe that this research offers a road map for future urban management studies through its innovative use of constructivist GT, as well as for future studies of how cultural memory can be leveraged to foster psychosocial well-being in HULs in other settings.

\subsection{Grounded Theory for HUL Research}

This paper has proposed a methodological approach by using GT to research the impact of cultural memory on the psychosocial well-being and QoL of users of, and visitors to, HULs. Firstly, it reviewed the related research themes and concepts to familiarise the readers with the research context. Thereafter, it demonstrated the value of GT in the study of the urban environment, in particular the management of HULs. Then, it specifically justified constructivist GT, a pragmatic and logical approach, with reference to its value for researchers working in areas that lack both broad-based data and theoretical frameworks. It showed that GT supported the use of knowledge gained in observation to further the efficacy of interview questions and analysis, constantly improving the quality of data and analysis as the research progresses. It also showed the value of using social media to form emotional communities that are helpful to gain valuable data that can be gathered remote from the site. Using this GT approach enabled the researchers to deepen their understanding of key concepts in informed GT research and constructivist theory. Moreover, this paper has demonstrated that constructivist GT is preferable to other models of GT due to the inherent flexibility of its epistemological foundation.

In summary, under constructivist GT, the iteration of research at every stage ensures relationships are constantly drawn between new and existing experience and knowledge. The paper looked at the methodological process of applying the constructivist GT approach across data gathering, management, and analysis to the extraction of results and theory development. Lastly, the strengths and limitations of this approach were outlined with a view to enabling future researchers to build on the suggested model.

It can be concluded that methodological tools must evolve to keep pace with the complexity and constant change that characterize urban phenomena. In this regard, it is suggested that constructivist GT offers a methodological roadmap for future urban management research and a robust grounding for studies of the role played by cultural memory, particularly the impact it has on human psychosocial well-being in HULs and other urban settings.

Author Contributions: Conceptualization, F.H. and R.T.; Formal analysis, F.H.; Investigation, F.H.; Methodology, F.H.; Resources, J.S. and R.T.; Software, F.H.; Supervision, J.S. and R.T.; Visualization, F.H.; Writing-original draft, F.H.; Writing-review \& editing, F.H., J.S. and R.T. All authors have read and agreed to the published version of the manuscript.

Funding: This research received no external funding.

Conflicts of Interest: The authors declare no conflict of interest.

Ethics Approval: All subjects gave their informed consent for inclusion before they participated in the study. The study was conducted in accordance with the Declaration of Helsinki, and the protocol was approved by the Human Research Ethics Committee of Curtin University, Australia. (HRE2018-0698). 


\section{Appendix A}

Table A1. This table shows the process of designing the interview questions. The research concepts/themes were extracted from the literature review phase and were broken to sub-themes (descriptions, components, and sub-components) in order to be covered by the interview questions.

\begin{tabular}{|c|c|c|c|c|}
\hline $\begin{array}{l}\begin{array}{l}\text { Research Concepts } \\
\text { (Themes) }\end{array} \\
\end{array}$ & Description & $\begin{array}{c}\text { Components } \\
\text { (Sub-Themes) }\end{array}$ & Sub-Components & First Proposed Measuring and Action Questions \\
\hline \multirow{2}{*}{$\begin{array}{l}\text { Well-being: } \\
\text { "A global assessment of a person's quality of life } \\
\text { according to his own chosen criteria" } \\
\text { (Shin and Johnson 1978). }\end{array}$} & \multirow{2}{*}{$\begin{array}{l}\text { Well-being is a holistic health condition containing } \\
\text { all the physical, cognitive, emotional, social, } \\
\text { physical, and spiritual dimensions (INEE 2017). }\end{array}$} & Tangible quality of life & $\begin{array}{ll}\text { - } & \text { Physical health } \\
\text { - } & \text { Features of the environment }\end{array}$ & $\begin{array}{l}\text { What do you feel when you are in this } \\
\text { place? Why? }\end{array}$ \\
\hline & & Intangible quality of life & $\begin{array}{l}\text { Psychological state } \\
\text { Personal beliefs } \\
\text { Social relationships }\end{array}$ & \\
\hline \multirow[t]{2}{*}{$\begin{array}{l}\text { Psychosocial well-being: } \\
\text { "Psychosocial well-being is a condition that } \\
\text { includes a full range of what is good for a person" } \\
\text { (INEE 2017). }\end{array}$} & \multirow[t]{2}{*}{$\begin{array}{l}\text { It is the close relationship between psychological } \\
\text { aspects and people's broader social experience } \\
\text { (INEE 2017). }\end{array}$} & \multirow[t]{2}{*}{$\begin{array}{ll}\text { - } & \text { Thoughts } \\
\text { - } & \text { Emotions } \\
\text { - } & \text { Behaviour } \\
\text { - } & \text { Relationships } \\
\text { - } & \text { Traditions } \\
\text { - } & \text { Memories } \\
\text { - } & \text { Culture }\end{array}$} & & $\begin{array}{l}\text { What do you feel when you are in this } \\
\text { place? Why? } \\
\text { What do you remember when you are in } \\
\text { this place? } \\
\text { How do you usually act in this place (stay } \\
\text { some time, pass quickly, play ... )? } \\
\text { Action question: }\end{array}$ \\
\hline & & & & $\begin{array}{l}\text { What are the things that you do to improve } \\
\text { your place experience? }\end{array}$ \\
\hline \multirow[t]{2}{*}{$\begin{array}{c}\text { Sense of place } \\
\text { “The particular experience of a person in a } \\
\text { particular setting (feeling stimulated, excited, } \\
\text { joyous, expansive, and so forth).” (Cross 2001). }\end{array}$} & \multirow{2}{*}{$\begin{array}{l}\text { It is composed of two different aspects. First is the } \\
\text { relationship to place, dealing with the ways that } \\
\text { people relate to places, and the types of bonds we } \\
\text { have with places. } \\
\text { Second is community attachment, dealing with the } \\
\text { depth and types of attachments to a person's } \\
\text { particular place (Cross 2001). }\end{array}$} & Relationships to place & $\begin{array}{ll}\text { - } & \text { Biographical bond } \\
\text { - } & \text { Spiritual bond } \\
\text { - } & \text { Ideological bond } \\
\text { - } & \text { Narrative bond } \\
\text { - } & \text { Commodified bond } \\
\text { - } & \text { Dependent bond }\end{array}$ & $\begin{array}{l}\text { To what extent do you feel related to this } \\
\text { place? Why? }\end{array}$ \\
\hline & & Community attachment & $\begin{array}{ll}- & \text { Rootedness } \\
- & \text { Place alienation } \\
\text { - } & \text { Relativity } \\
\text { - } & \text { Placelessness }\end{array}$ & $\begin{array}{l}\text { How long have you been using this place and } \\
\text { how much are you able to interact with its } \\
\text { the community? }\end{array}$ \\
\hline
\end{tabular}


Table A1. Cont.

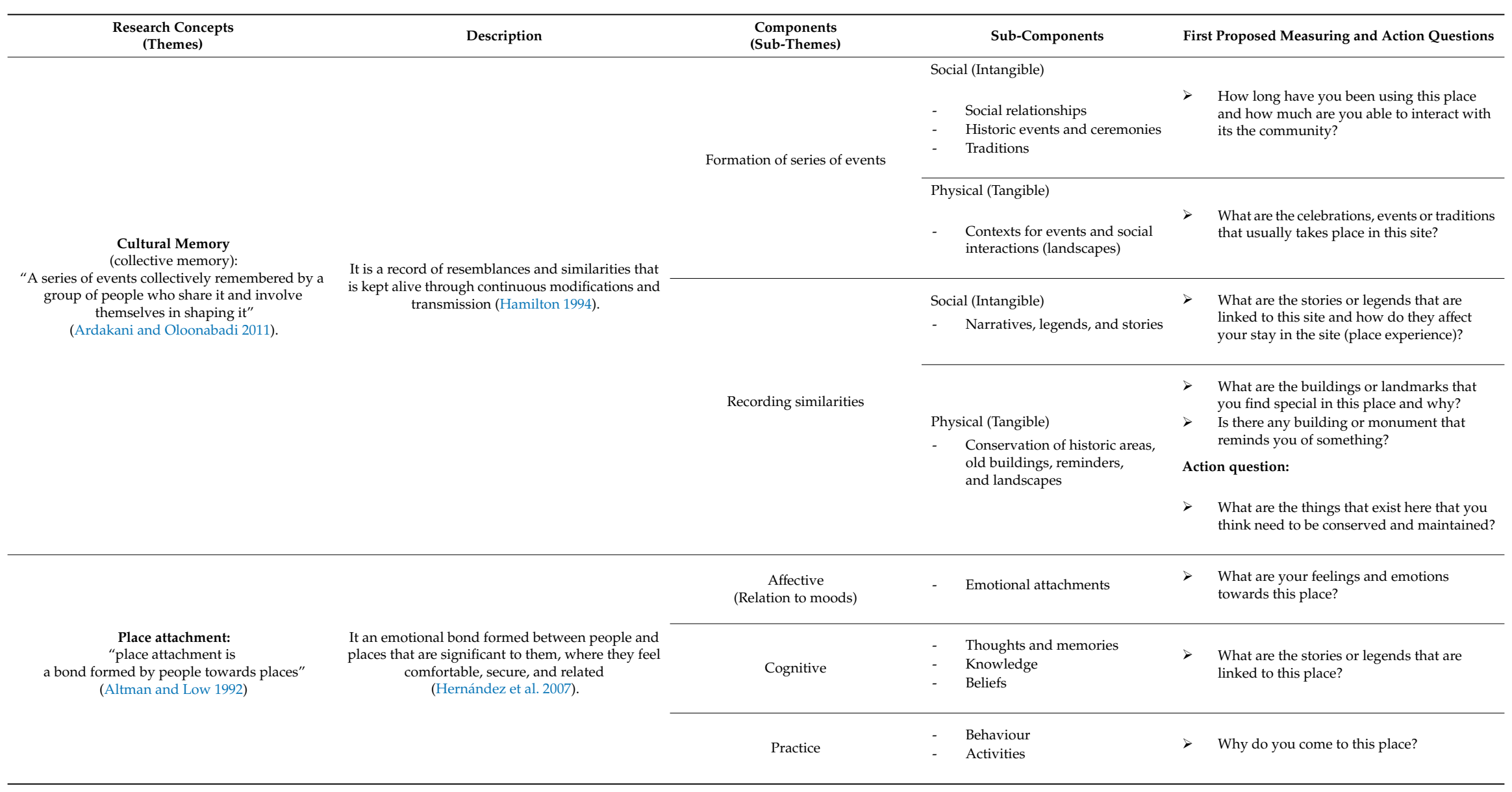


Table A1. Cont.

\begin{tabular}{|c|c|c|c|c|}
\hline $\begin{array}{l}\text { Research Concepts } \\
\text { (Themes) }\end{array}$ & Description & $\begin{array}{l}\text { Components } \\
\text { (Sub-Themes) }\end{array}$ & Sub-Components & First Proposed Measuring and Action Questions \\
\hline \multirow[t]{2}{*}{$\begin{array}{l}\text { Place identity: } \\
\text { "Set of place features that guarantee the place's } \\
\text { distinctiveness and continuity in time" } \\
\text { (Lewicka 2008). }\end{array}$} & \multirow[t]{2}{*}{$\begin{array}{l}\text { It is found in the places that make us feel unique, } \\
\text { in control, and happy about ourselves; is aligned } \\
\text { with our personal ideas of who we are; and is more } \\
\text { likely to be comprehended into our identity } \\
\text { structure (Anton and Lawrence 2014). }\end{array}$} & $\begin{array}{l}\text { Continuity: } \\
\text { Maintaining identity in place over } \\
\text { time (Twigger-Ross and Uzzell 1996) }\end{array}$ & & $\begin{array}{l}\text { What are the things that you think have been } \\
\text { kept and passed from one generation to } \\
\text { another, either physically or even a habit or } \\
\text { a tradition? } \\
\text { What are the changes that happened to } \\
\text { this site? } \\
\text { What are the things that are gone and that } \\
\text { you hoped are still found? }\end{array}$ \\
\hline & & $\begin{array}{c}\text { Distinctiveness: } \\
\text { Unique and different place } \\
\text { characteristics (Twigger-Ross and } \\
\text { Uzzell 1996) }\end{array}$ & & $\begin{array}{l}\text { In your opinion, describe in one sentence } \\
\text { what makes this site unique. } \\
\text { Action question: } \\
\text { What could be done to make the place more } \\
\text { unique from other places? }\end{array}$ \\
\hline \multirow{2}{*}{$\begin{array}{l}\text { Landscape approach: } \\
\text { “Landscape is a place to which a person becomes } \\
\text { attached because of the nostalgia and the } \\
\text { memories to which it gives rise" (Hoteit 2015). }\end{array}$} & \multirow{2}{*}{$\begin{array}{l}\text { Landscape is the result of the way various } \\
\text { elements of both the natural (the effect of geology, } \\
\text { soils, climate, flora, and fauna) and the cultural } \\
\text { (the effect of historical and current human } \\
\text { interventions) interact together and are } \\
\text { appreciated by a person (Swanwick 2002). }\end{array}$} & Natural & $\begin{array}{ll}- & \text { Geology } \\
\text { - } & \text { Soils } \\
\text { - } & \text { Climate } \\
\text { - } & \text { Flora } \\
\text { - } & \text { Fauna }\end{array}$ & \\
\hline & & Cultural & $\begin{array}{ll}\text { Intangible } \\
\\
-\quad \text { History } \\
-\quad \text { Stored memory } \\
-\quad \text { Traditions } \\
- & \text { Emotions }\end{array}$ & $\begin{array}{l}\text { What do you know about this site's } \\
\text { historical background? } \\
\text { How nostalgic do you become at this place? } \\
\text { What celebrations, events, or traditions } \\
\text { usually take place on this site? } \\
\text { What are your feelings and emotions } \\
\text { towards this place? }\end{array}$ \\
\hline
\end{tabular}




\section{References}

Achora, Susan, and Gerald Amandu Matua. 2016. Essential methodological considerations when using grounded theory. Nurse Researcher 23: 31-36. [CrossRef] [PubMed]

Alexandria, Portal. 2019. Available online: http://www.alexandria.gov.eg/Alex/english/index.aspx (accessed on 8 September 2019).

Alexandria, Portal. 2020. Available online: https://www.facebook.com/alexandria1900/photos/a.364092033619757/ 2326206160741658/ (accessed on 8 October 2018). First publish 1900.

Alexandria Egypt Land Meets Water. 2012. Sounds Like Wish. Available online: https://soundslikewish.com/tag/ alexandria-egypt/ (accessed on 13 January 2020).

Allen, Natalie, and Mark Davey. 2018. The Value of Constructivist Grounded Theory for Built Environment Researchers. Journal of Planning Education and Research 38: 222-32. [CrossRef]

Altman, Irwin, and Setha M. Low. 1992. Place Attachment. Edited by Irwin Altman and Setha M. Low. New York: Plenum Press.

Alves de Sousa, Célio A. A., and Paul H. J. Hendriks. 2006. The Diving Bell And the Butterfly. The Need for Grounded Theory in Developing a Knowledge-based View of Organizations. Organizational Research Methods 9: 315-38. [CrossRef]

Anton, Charis E., and Carmen Lawrence. 2014. Home is where the heart is: The effect of place of residence on place attachment and community participation. Journal of Environmental Psycholgy 40: 451-61. [CrossRef]

Ardakani, Maryam Keramati, and Seyyed Saeed Ahmadi Oloonabadi. 2011. Collective memory as an efficient agent in sustainable urban conservation. Procedia Engineering 21: 985-88. [CrossRef]

Asem, Dalia. 2009. El Zanqa Market a Folkloric Painting Drawn by the Alexandrian Traditional Girls (Arabic Source). Available online: http://archive.aawsat.com/details.asp? section $=67 \&$ article $=512941$ \&issueno= 11080\#.WG0ZL027rug (accessed on 12 January 2020).

Awad, Mohamed. 1996. The Metamorphosis of Mansheyah. In Alexandrie en Égypte(Alexandria in Egypt). Edited by Kenneth Brown, Hannah Davis Taieb, Edwar al-Kharrat and Adel Abou Zahra. (Special issue 8/9). Cairo: Méditerranéennes(French Periodical). Available online: https://thewallsofalex.blogspot.com/2014/07/themetamorphosis-of-mansheya.html (accessed on 14 March 2020).

Aysegul, Kaya Tanriverdi. 2016. Method for Assessment of the Historical Urban Landscape. Procedia Engineering 161: 1697-703. [CrossRef]

Baker, Sarah, and Rosalind Edwards. 2012. How Many Qualitative Interviews is Enough. National Centre for Research Methods Review Paper. Available online: http://eprints.ncrm.ac.uk/2273/4/how_many_interviews. pdf (accessed on 14 March 2020).

Bandarin, Francesco, and Ron van Oers. 2015. Reconnecting the City: The Historic urban Landscape Approach and the Future of urban Heritage. Edited by Francesco Bandarin and Ron van Oers. Chichester: Wiley Blackwell.

Boyer, M. Christine. 1994. The City of Collective Memory: Its Historical Imagery and Architectural Entertainments/M. Christine Boyer. Cambridge: MIT Press.

Brian, W. Eisenhauer, Richard S. Krannich, and Dale J. Blahna. 2000. Attachments to Special Places on Public Lands: An Analysis of Activities, Reason for Attachments, and Community Connections. Society E Natural Resources 13: 421-41. [CrossRef]

Carone, Paola, Pasquale De Toro, and Alfredo Franciosa. 2017. Evaluation of Urban Processes on Health in Historic Urban Landscape Approach: Experimentation in the Metropolitan Area of Naples (Italy). Kvalita Inovácia Prosperita 21: 202. [CrossRef]

Charmaz, Kathy. 2000. Grounded theory: Objectivist and constructivist methods. In The Handbook of Qualitative Research. Edited by Norman K. Denzin and Yvonna Sessions Lincoln. London: Sage Publications, pp. 509-35.

Charmaz, Kathy. 2005. Grounded Theory in the 21st Century: Applications for Advancing Social Justice Studies. In The Sage Handbook of Qualitative Research, 3rd ed. Edited by Norman K. Denzin and Yvonna Sessions Lincoln. Thousand Oaks: Sage Publications Ltd., pp. 507-35.

Charmaz, Kathy. 2006. Constructing Grounded Theory: A Practical Guide through Qualitative Analysis/Kathy Charmaz. London: SAGE Publications.

Charmaz, Kathy. 2015. Grounded Theory: Methodology and Theory Construction. In International Encyclopedia of the Social \& Behavioral Sciences, 2nd ed. New York: Elsevier, pp. 402-7. [CrossRef]

Charmaz, Kathy. 2014. Constructing Grounded Theory/Kathy Charmaz, 2nd ed. London: SAGE. 
Cheshmehzangi, Ali, and Tim Heat. 2012. Urban Identities: Influences on Socio-Environmental Values and Spatial Inter-Relations. Procedia-Social and Behavioral Sciences 36: 253-64. [CrossRef]

Compton, Mike, and Sean Barrett. 2016. A Brush with Research: Teaching Grounded Theory in the Art and Design Classroom. Universal Journal of Educational Research 4: 335. [CrossRef]

Cross, Jennifer E. 2001. What is Sense of Place? Paper presented at 12th Headwaters Conference, Western State College, CO, USA, November 2-4; Available online: http://western.edu/sites/default/files/documents/cross_ headwatersXII.pdf (accessed on 10 March 2019).

Daengbuppha, Jaruwan, Nigel Hemmington, and Keith Wilkes. 2006. Using grounded theory to model visitor experiences at heritage sites: Methodological and practical issues. Qualitative Market Research 9: 367-88. [CrossRef]

Deyaa, Nada. 2016. Another legacy wasted: Alexandria's Al-Salam theatre is demolished. Daily News/Egypt. Available online: https:/wwww.dailynewssegypt.com/2016/06/26/another-legacy-wasted-alexandrias-alsalam-theatre-demolished/ (accessed on 24 March 2020).

Eyles, John. 1985. Senses of Place. Warrington: Silverbrook Press.

Eyles, John. 2008. Qualitative Approaches in the Investigation of Sense of place and Health Rellations. In Sense of Place, Health, and Quality of Life. Edited by John Eyles and Allison Williams. Aldershot and Burlington: Ashgate Publishing.

Flick, Uwe. 2002. An Introduction to Qualitative Research/Uwe Flick, 2nd ed. London: SAGE.

Friedmann, John. 1998. Planning theory revisited. European Planning Studies 6: 245-53. [CrossRef]

Gary, L.Evans. 2013. A Novice Researcher's First Walk Through the Maze of Grounded Theory: Rationalization for Classical Grounded Theory. The Grounded Theory Review 12: 37-55.

Giuliani, Maria Vittoria. 2003. Theory of attachment and place attachment. In Psychological Theories for Environmental Issues. Edited by Mirilia Bonnes and Terence Lee. London: Routledge, pp. 137-70.

Glaser, Barney G. 1967. The Discovery of Grounded Theory Strategies for Qualitative Research. Edited by Barney G. Glaser and Anselm L. Strauss. Chicago: Aldine Pub. Co.

González-Teruel, Aurora, and M. Francisca Abad-García. 2012. Grounded theory for generating theory in the study of behavior. Library E Information Science Research 34: 31-6. [CrossRef]

GoogleMaps. n.d. Alexandria, Egypt. Available online: https://www.google.com/maps/place/Alexandria, +Alexandria+Governorate,+Egypt/@31.2387263,29.7274058,10.25z/data=!4m5!3m4!1s0x14f5c49126710fd3: 0xb4e0cda629ee6bb9!8m2!3d31.2000924!4d29.9187387 (accessed on 10 June 2020).

Goulding, Christina. 1998. Grounded theory: The missing methodology on the interpretivist agenda. Qualitative Market Research 1: 50-7. [CrossRef]

Gregory, Jenny. 2015. Connecting with the past through social media: The 'Beautiful buildings and cool places Perth has lost' Facebook group. International Journal of Heritage Studies 21: 22-45. [CrossRef]

Halbwachs, Maurice. 1992. On collective memory / Maurice Halbwachs. Edited, Translated, and with an Introduction by Lewis A. Coser. Chicago: University of Chicago Press.

Hamilton, Paula. 1994. The Knife Edge: Debates about Memory and History. In Memory and History in Twentieth-Century Australia. Edited by Kate Darian-Smith and Pauline Hamilton. Melbourne: Oxford University Press, pp. 9-32.

Hanafi, Mohamed Assem. 1993. Development and Conservation with Special Reference to the Turkish Town of Alexandria. Ph.D. thesis, University of York, York, UK. Available online: http://etheses.whiterose.ac.uk/id/ eprint/10921 (accessed on 18 June 2020).

Hay, Robert. 1998. Sense of Place in Developmental Context. Journal of Environmental Psychology 18: 5-29. [CrossRef]

Hernández, Bernardo, Maria Carmen Hidalgo, Maria Salazar-Laplace, and Stephany Hess. 2007. Place attachment and place identity in natives and non-natives. Journal of Environmental Psychology 27: 310-19. [CrossRef]

Holton, Judith. 2010. The Coding Process and Its Challenges. The Grounded Theory Review 9: 265-289.

Hoteit, Aida. 2015. Role of the Landscape in the Preservation of Collective Memory and the Enhancement of National Belonging. Canadian Social Science 11: 42-49. [CrossRef]

Hummon, David M. 1992. Community attachment: Local sentiment and sense of place. In Place Attachment. Edited by Setha M. Low and Irwin Altman. New York: Plenum Press.

Hussein, Fatmaelzahraa, John Stephens, and Reena Tiwari. 2020a. Cultural Memories and Sense of Place in Historic Urban Landscapes: The Case of Masrah Al Salam, the Demolished Theatre Context in Alexandria, Egypt. Land (Basel) 9: 264. [CrossRef] 
Hussein, Fatmaelzahraa, John Stephens, and Reena Tiwari. 2020b. Cultural Memories for Better Place Experience: The Case of Orabi Square in Alexandria, Egypt. Urban Science 4: 14. [CrossRef]

Hussein, Fatmaelzahraa, John Stephens, and Reena Tiwari. 2020c. Memory for Social Sustainability: Recalling Cultural Memories in Zanqit Alsitat Historical Street Market, Alexandria, Egypt. Sustainability 12: 8141. [CrossRef]

INEE. 2017. INEE Thematic Issue Brief: Psychosocial Well-Being. Available online: http://www.humanitarianinfo. $\mathrm{org} /$ iasc/content/products (accessed on 10 January 2020).

Ingold, Tim, and Jo Lee Vergunst. 2008. Ways of Walking: Ethnography and Practie on Foot. Edited by Tim Ingold and Jo Lee Vergunst. Aldershot: Ashgate Publishing.

Jackson, John Brinckerhoff. 1994. A Sense of Place, a Sense of Time/John Brinckerhoff Jackson. New Haven: Yale University Press.

Jahanbakhsh, Heidar, Mostafa Hosseini Koumleh, and Fatemeh Sotoudeh Alambaz. 2015. Methods and Techniques in Using Collective Memory in Urban Design: Achieving Social Sustainability in Urban Environments. Cumhuriyet University Faculty of Science Journal (CSJ) 36: 13.

Kawulich, Barbara.B. 2005. Participant Observation as a Data Collection Method. Available online: http: //www.qualitative-research.net/index.php/fqs/article/view/466/996 (accessed on 15 May 2020).

Kraus, Wolfgang. 2006. The narrative negotiation of identity and belonging. Narrative Inquiry 16: 103-11. [CrossRef]

Kyle, Gerard T., Andrew J. Mowen, and Michael Tarrant. 2004. Linking place preferences with place meaning: An examination of the relationship between place motivation and place attachment. Journal of Environmental Psychology 24: 439-54. [CrossRef]

Lewicka, Maria. 2008. Place attachment, place identity, and place memory: Restoring the forgotten city past. Journal of Environmental Psychology 28: 209-31. [CrossRef]

Li, Na. 2010. Preserving Urban Landscapes as Public History: The Chinese Context. The Public Historian 32: 51-61. [CrossRef]

Li, Xingwei, Jianguo Du, and Hongyu Long. 2019. Green Development Behavior and Performance of Industrial Enterprises Based on Grounded Theory Study: Evidence from China. Sustainability 11: 4133. [CrossRef]

Meng, Xiangrui. 2013. Scalable simple random sampling and stratified sampling. International Conference on Machine Learning, ICML 2013: 1568-76.

Mills, Jane, Ann Bonner, and Karen Francis. 2016. The Development of Constructivist Grounded Theory. International Journal of Qualitative Methods 5: 25-35. [CrossRef]

Molavi, Mehrnaz, Imira Rafizadeh Malekshah, and Elaheh Rafizadeh Malekshah. 2017. Is Collective Memory Impressed By Urban Elements? Management Research and Practice 9: 14-27.

Morse, Janice Margaret. 1994. Designing funded qualitative research. In Handbook of Qualitative Research, 2nd ed. Edited by Norman K. Denzin and Yvonna Sessions Lincoln. Thousand Oaks: Sage.

Morgan, Ahmed. 2016. Six Touristic Buildings Were Demolished from Alexandria by the End of 2016 (Arabic Source). Available online: https://www.soutalomma.com/465080 (accessed on 12 January 2020).

Nora, Pierre. 1989. Between memory and history: Les lieux de memoire. Memory and Counter-Memory 26: 7-24.

Nvivo10. 2020. About Nodes Nvivo10 for Windos Help. Available online: https://help-nv10.qsrinternational.com/ desktop/concepts/about_nodes.htm (accessed on 10 September 2020).

Olsen, Wendy. 2004. Triangulation in Social Research: Qualitative and Quantitative Methods Can ReallyBe Mixed. In Developments In Sociology. Edited by Michael Haralambos and M. Holborn. Ormskirk: Causeway Press Ltd.

Patrick, J. Bateman, Crystal Pike Jacqueline, and S. Butler Brian. 2011. To disclose or not: Publicness in social networking sites. Information Technology \& People 24: 78-100. [CrossRef]

Ramkissoon, Haywantee, Betty Weiler, and Liam David Graham Smith. 2012. Place attachment and pro-environmental behaviour in national parks: The development of a conceptual framework. Journal of Sustainable Tourism 20: 257-76. [CrossRef]

Relph, Edward C. 1976. Place and Placelessness/E. Relph. Research in Planning and Design A Revision of the Author's Thesis. London: University of Toronto.

SDU (University of Southern Denmark). 2020. Better Thesis: Your online support. In A Joint Production by: University of Southern Denmark Library and the Unit for Health Promotion Research. Copenhagen: University of Copenhagen, Department of International Health and Faculty Library of Natural and Health Sciences. Available online: http://betterthesis.dk/research-methods/empirical-studies (accessed on 20 September 2020). 
Shamai, Shmuel, and Zinaida Ilatov. 2005. Measuring Sense of Place: Methodological Aspects. Tijdschrift Voor Economische en Sociale Geografie 96: 467-76. [CrossRef]

Shin, D. C., and D. M. Johnson. 1978. Avowed happiness as an overall assessment of the quality of life. Social Indicators Research 5: 475-92. [CrossRef]

Skene, Allyson. 2016. Writing a Critical Review. Available online: https://ctl.utsc.utoronto.ca/twc/sites/default/ files/CritReview.pdf (accessed on 15 August 2020).

Steele, Fritz. 1981. The Sense of Place/Fritz Steele. Boston: CBI Pub. Co.

Strauss, Anselm, and Juliet Corbin. 1998. Basics of Qualitative Research: Techniques and Procedures for Developing Grounded Theory, 2nd ed. Thousand Oaks: Sage Publications, Inc.

Strauss, Anselm. 1990. Basics of Qualitative Research: Grounded Theory Procedures and Techniques/Anselm Strauss, Juliet Corbin. Newbury Park: Sage Publications.

Swanwick, Carys. 2002. Landscape Character Assessment: Guidance for England and Scotland. Sheffield: UK Countryside Agency Publications. Available online: https://www.nature.scot/sites/default/files/2018-02/ Publication\%202002\%20-\%20Landscape\%20Character\%20Assessment\%20guidance\%20for\%20England\% 20and\%20Scotland.pdf (accessed on 16 September 2020).

Tuan, Yi-Fu. 1980. The Significance of the Artifact. Geographical Review 70: 462-72. [CrossRef]

Twigger-Ross, Clare L., and David L. Uzzell. 1996. Place and Identity Processes. Journal of Environmental Psychology 16: 205-20. [CrossRef]

Twitter.com. 2018. French Gardens 1930s [Photo/jpg]. Available online: https://pbs.twimg.com/media/ De4aZMEXkAArk7H.jpg:large (accessed on 14 August 2019).

Ujang, Norsidah, and Khalilah Zakariya. 2015. Place Attachment and the Value of Place in the Life of the Users. Procedia-Social and Behavioral Sciences 168: 373-80. [CrossRef]

UNESCO. 2016. The Hul Guidebook. Paper presented at the 15th World Conference of the League of Historical Cities, Bad Ischl, Austraia, June 5-10. Available online: http://historicurbanlandscape.com/themes/196/ userfiles/download/2016/6/7/wirey5prpznidqx.pdf (accessed on 12 March 2020).

Van der Hoeven, Arno. 2019. Historic urban landscapes on social media: The contributions of online narrative practices to urban heritage conservation. City, Culture and Society 17: 61-68. [CrossRef]

Williams, Allison, Christine Heidebrecht, Lily Demiglio, John Eyles, David Streiner, and Bruce Newblod. 2008. Developing a psychometric scale for measuring sense of place and health: An application of fact design. In Sense of Place, Health, and Quality of Life. Edited by John Eyles and Allison Williams. Aldershot: Ashgate Publishing.

Williams, Daniel R., Michael E. Patterson, Joseph W. Roggenbuck, and Alan E. Watson. 1992. Beyond the commodity metaphor: Examining emotional and symbolic attachment to place. Leisure Sciences 14: $29-46$. [CrossRef]

Williams, Daniel R., and Susan I. Stewart. 1998. Sense of place: An elusive concept that is finding a place in ecosystem management. Journal of Forestry 66: 18-23.

Wilson, Kimberley, and Cheryl Desha. 2016. Engaging in design activism and communicating cultural significance through contemporary heritage storytelling: A case study in Brisbane, Australia. Journal of Cultural Heritage Management and Sustainable Development 6: 271-86. [CrossRef]

Zeinobia. 2016. Farewell El-Salam Theatre of Alexandria "Updated". Egyptian Chronicles. Available online: https://egyptianchronicles.blogspot.com/2016/06/june-13-2016-at-1225am.html (accessed on 7 June 2018).

Publisher's Note: MDPI stays neutral with regard to jurisdictional claims in published maps and institutional affiliations.

(C) 2020 by the authors. Licensee MDPI, Basel, Switzerland. This article is an open access article distributed under the terms and conditions of the Creative Commons Attribution (CC BY) license (http://creativecommons.org/licenses/by/4.0/). 